\title{
Geðheilsa ungs fólks
}

Á æviskeiði ungdómsáranna er grunnurinn lagður að framtíðinni. Petta er mikilvægur tími par sem fyrstu skrefin eru stigin inn í fullorðinsárin og hornsteinn lagður að sjálfstæðu lífi. Líkamleg heilsa er með besta móti en á sama tíma er sjúkdómsbyrði vegna geðsjúkdóma hvað mest. Prír fjórðu alvarlegra geðsjúkdóma byrja fyrir 24 ára aldur. ${ }^{1}$ Sjúkdómar eins og geðklofi, geðhvörf, kvíðasjúkdómar, vímuefnavandi og átraskanir. Oft og tíðum er um að ræða erfiða blöndu af fleiri en einum sjúkdómi.

Vísbendingar eru um að geðheilsu ungs fólks á Íslandi fari hrakandi, með vaxandi einkennum punglyndis og kvíða. ${ }^{2}$ Petta er mikið áhyggjuefni fyrir okkur öll. Margt getur spilað inn í pessa mynd. Rannsóknir sýna að svefntími unglinga er styttri en áður. ${ }^{3}$ Áskoranir ungs fólks hafa breyst mikið á síðustu árum, meðal annars með byltingu í samfélagsmiðlum og auknu álagi í skóla með styttingu framhaldsnáms. Vandamálið er að geðrænn vandi á pessu mikilvæga æviskeiði getur haft alvarlegar afleiðingar og varpað skugga langt inn í framtíð einstaklingsins og peirra sem næst standa. Pað er staðreynd að pað að glíma við geðrænan vanda milli 18-25 ára aldurs tengist minni atvinnupátttöku, lægri tekjum og verri félagslegri stöðu um prítugt. ${ }^{4}$

Fátt er mikilvægara fyrir samfélag okkar en að efla geðheilsu okkar unga fólks. En einmitt par sem heilbrigðiskerfið ætti að vera sterkast eru veikleikar. Pessir veikleikar kerfisins valda pví að oft og tíðum gengur illa að mæta nægjanlega vel pörfum ungs fólks og peirra nánustu.

Раð má segja að ef til vill sé heilbrigðiskerfið okkar byggt á grunnkerfi vefrænna sjúkdóma. Aðalpunginn er á sjúkdómsbyrðina seinni hluta ævinnar. Of lítil áhersla er pví lögð á heilsu ungs fólk pví sjúkdómsbyrði peirra er almennt lítil miðað við eldri hópinn pegar einblínt er á líkamlega heilsu. Hér gleymist geðheilsan. Frekari kerfisvandi er síðan innan sjálfrar geðheilbrigðispjónustunnar. Á miðjum ungdómsárunum, við 18 ára aldur, eru skörp skil milli pjónustu við börn og unglinga annars vegar og fullorðna hins vegar. Flæðið yfir í fullorðinshluta geðheilbrigðiskerfisins gengur pví miður oft treglega. Til að auka vandann enn frekar leitar ungt fólk sér síður aðstoðar vegna geðræns vanda og dettur frekar úr meðferð. ${ }^{5}$

Með öflugum forvörnum og viðeigandi úrræðum má bæta geðheilsu okkar unga fólks. Við pekkjum vel helstu áhættupætti geðræns vanda, svo sem misnotkun og vanrækslu í æsku, áföll, fátækt, félagslega einangrun, erfiðleika í skóla, fíknivanda, mismunun og atvinnuleysi. Við purfum íhlutanir sem miða að pví að draga úr áhrifum pessara pátta, eins og fjallað er um í ársgamalli skýrslu starfshóps um aðgerðir til að fækka sjálfsvígum á Íslandi. ${ }^{6}$ Par er meðal annars bent á mikilvæga pætti eins og að efla uppvaxtarskilyrði barna, forvarnir og geðrækt í skólastarfi og á vinnustöðum og heilsueflandi samfélög. Í skýrslunni er einnig lögð áhersla á að efla úrræði í nærumhverfi, meðal annars með lágpröskuldapjónustu.

Meðferðarúrræði sem í boði eru fyrir ungt fólk purfa að vera sniðin að pörfum pess. Ungt fólk vill gott aðgengi að aðstoð pegar pað parf á henni að halda og samfellu í meðferð. Öruggt og jafnframt vinalegt en sveigjanlegt umhverfi par sem meðferð byggist á samvinnu og virðingu.

En sem betur fer eru samfélagið og ráðamenn að hlusta. Margt gott er að gerast. Umræðan um geðrænan vanda er opnari og pað hefur dregið úr fordómum. Byggð hefur verið upp öflug pjónusta við ungt fólk með geðrofssjúkdóma á Laugarásnum á geðsviði Landspítala. Fyrirhugað er að efla pjónustu við ungmenni með alvarlegan neysluvanda með аðkomu margra aðila, meðal annars Landspítala. Verið er að fjölga sálfræðingum á heilsugæslustöðvum og til stendur að auka pá pjónustu í framhaldsskólum. Með vorinu opnar Bergið Headspace á Suðurgötu í miðbæ Reykjavíkur. Petta er stuðnings- og ráðgjafasetur fyrir ungt fólk að ástralskri fyrirmynd. Hér er að koma inn öflug starfsemi sem reynir að mæta peirri pörf sem opinbera kerfið hefur ekki ráðið nógu vel við hingað til. Pessi starfsemi nýtur stuðnings ráðamanna og einkennist af samvinnu og von um að ná fyrr til unga fólksins og styðja pað við að leysa úr sínum vanda. Pannig er leitast við að fyrirbyggja alvarleg veikindi síðar.

Góð geðheilsa á unglingsárunum leggur grunninn að heilbrigði í framtíðinni. Fyrst og fremst fyrir einstaklinginn og umhverfi hans, en ekki síður fyrir allt samfélagið. Рað er pví til mikils að vinna að fjárfesta í geðheilsu okkar unga fólks. Krafturinn og stuðningurinn sem einkennir pessi mál í samfélaginu pessa dagana er fagnaðarefni og gefur von til framtíðar.

\section{Heimildir}

1. Kessler RC, Berglund P, Demler O, Jin R, Merikangas KR, Walters EE. Lifetime prevalence and age-of-onset distributions of DSM-IV disorders in the National Comorbidity Survey Replication. Arch Gen Psychiatry 2005; 62: 593-602.

2. Ungt fólk 2018. Lýðheilsa ungs fólks í Reykjavík. Rannsóknir og greining 2018.

3. Twenge JM, Krizan Z, Hisler G. Decreases in self-reported sleep duration among U.S. adolescents 2009-2015 and association with new media screen time. Sleep Med 2017; 39: 47-53.

4. Gibb SJ, Fergusson DM, Horwood LJ. Burden of psychiatric disorder in young adulthood and life outcomes at age 30. Br J Psychiatry 2010; 197: $122-7$

5. Gulliver A, Griffiths MK, Christensen H. Perceived barriers and facilitators to mental health help-seeking in young people: a systematic review. BMC Psychiatry 2010; 10: 113.

6. Daníelsdóttir S. Aðgerðaráætlun til að fækka sjálfsvígum á Íslandi. Niðurstöður starfshóps, apríl 2018.

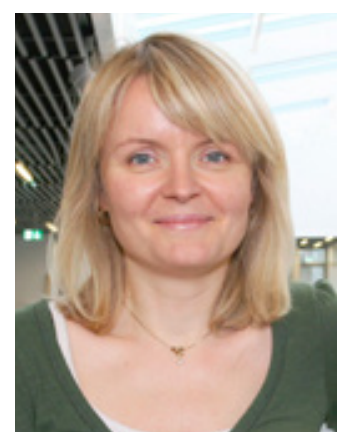

\section{Nanna Briem}

yfirlæknir á geðsvið̌i Landspítala

nannabri@landspitali.is

\section{Youth mental health}

Nanna Briem, MD consultant psychiatrist, Department of Psychiatry, Landspitali University Hospital

doi.org/10.17992//bl.2019.05.229 